\title{
Knapmageriet i Tønder amt
}

\section{Et bidrag til husflidens historie")}

\author{
Af $F$. C. C. Linvald
}

Rundt om i Danmarks magre egne har bønder og husmænd fra gammel tid søgt at bøde på deres ringe kår. »Jydepotterne var således i en lang årrække en betydelig indtægtskilde for de fattigebeboere $i$ omegnen af Varde. sUldjyderne\& $i$ Hammerum herred har i mange tider vandret omkring $i$ landet med deres tunge bylt på nakken og gjort deres ufrugtbare hjemstavn bekendt. Ofte har de bragt velstand til huse, og undertiden har de erhvervet sig formuer, så de har kunnet hæve sig op over og ud af deres stand. Den ş̧nderjydske kniplingsindustri er et lignende udslag af den danske bondebefolknings omsigt, flid og dygtighed. Den har her vist sin evne til at frembringe en industriartikel af en så fremragende art, at den er bleven bekendt og skattet langt ud over landets. grænser. I det folgende vil blive omtalt en husindustri, der i sammenligning med de ovenstående er mindre betydelig, men alligevel fortjener at drages frem, for at den ikke helt skal gå i glemme. Talen er om knapmageriet i T $\phi$ nder amt.

\$I den ufrugtbare del af Tønder amt, « skriver kgl. fabrikdirekt $\varnothing \mathrm{r}$ Lehmann $\mathrm{i}$ året 1823 , sstræber de fattige indbyggere ved mange slags husindustri at bøde på afsavn af de gaver, som naturen har forundt deres lykkeligere naboere. Her væves vadmel og

*) Denne artikel er oprindelig trykt i sFra Arkiv og Museume, udgivet af Østifternes historisk-topographiske Selskab, 1918. På dette tidspunkt udkom Sønderjyske årbøger på grund af verdenskrigen ikke, ellers ville artiklens plads have været her. $\mathrm{Da}$ vi mener, at artiklen bør gøres lettere tilgængelig for sønderjyske læsere, har vi besluttet at foretage et genoptryk og bringer den med tilladelse af familien i dette hefte. 
andre grove $t \not j e r$, bindes huer og strømper og forfærdiges de bekendte kniplinger. Derved er fremstået uden underst $\varnothing$ ttelse og uden bram en del landfabrikation eller industri, der er det eneste middel, hvorpå i slige egne livets første fornødenheder kunne erhverves. - Til denne landindustri hører og knapmageriet. $\ll^{1}$ )

Det var tinknapper, der forfærdigedes. Materialet skaffede man sig ved at opk $\emptyset$ be gammelt tin, enten på auktionerne eller omkring hos landbefolkningen. Der var to slags knapper: de flade og mindre, der nærmest brugtes til benklæder, og de st $\varnothing r r e$, mere kunstfærdige, som lavedes af to stykker, der loddedes sammen; de benyttedes til trøjer. Knapperne støbtes i en form; til udpyntningen og afdrejningen brugtes et drejelad. Når de var færdige, blev de fæstet på et stykke stift papir, og de holdtes fast ved, at et siv blev trukket gennem $\varnothing$ jerne.

Knapmageriet var i h $\varnothing \mathbf{j}$ grad begrænset af tid og sted. Skatteog mandtalslisterne for $\mathbf{1 7 8 9}$ viser, at der på den tid var knapmagere spredt over Slogs- og Kærherred i Tønder amt. I f $\varnothing$ rstnævnte herred var der syv skattepligtige knapmagere, og af disse var de 6 bosiddende $i$ Hostrup sogn; $i$ det sydlige Kærherred var der 8 . Ved folketællingen, der fandt sted $i$ året 1835 , finder vi i Slogsherred 67 knapmagere, og af disse $61^{*}$ ) i Hostrup sogn, medens der i Kærherred kun var 8.

Hostrup sogn ligger $\emptyset$ st for T $\emptyset$ nder; dets jorder grænser op til denne bys grund. Sognet er ret stort; det består af landsbyerne Hostrup, Rørkær, Jejsing og Solderup. 1835 var beboernes antal

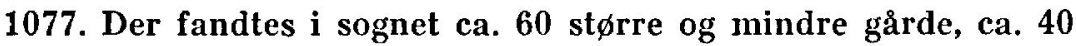
huse med jord og ca. 110 huse uden jord.

Medens knapmageriet nærmest holdt sig inden for Hostrup sogns grænser, blev markedet for knapperne lidt efter lidt det hele land. Indtil slutningen af det 18 . århundrede var handelen begrænset til den nærmest liggende egn, men efter at Hostrup sogn havde fået fuldstændig overtaget, og produktionen af knapperne stadig blev større og større, s $\varnothing$ gte man nye veje for afsætningen. Man går over Kongeåen, og snart er hele Jylland opland for de dygtige og energiske knapmagere; derefter f $\phi$ lger Sjælland

*) I dette antal er indbefattet 6 svende og 6 lærlinge. 
og til sidst Fyn og de фvrige фer. De »tønderske knapper« var nu kendt over hele landet.

Det er denne ejendommelige og ingenlunde ubetydelige husindustri, dens udvikling og dens udøveres ihærdige kamp for at sikre deres eksistensbetingelser, der her vil blive behandlet.

I.

Når knapmageriet i Tønder amt er begyndt, har det ikke været muligt at få oplyst, men at det er en ret gammel industri, er der ingen tvivl om. Flere ans $\varnothing$ gere om at få tilladelse til at forfærdige knapper udtaler $i$ begyndelsen af forrige århundrede, at knapmageriet i Slogsherred har fundet sted $\gg$ i umindelige tider $\left.\star^{2}\right)$, og herredsfoged B. Feddersen i samme herred bemærker 1824, at »det har været drevet $i$ mere end hundrede år $\left.\ll^{2}\right)^{*}$ ). Det var $\operatorname{dog}$ først efter krigens oph $\phi \mathbf{r} 1814$, at knapmageriet havde sin gode tid. Det kneb den gang meget for den sønderjyske hondestand. Den fik næsten intet udbytte af sine ejendomme. B $\phi$ nderne måtte tildels selv udrette arbejdet på deres gårde; de havde ikke råd til at holde medhjælp. Husmændene og de endnu fattigere indsiddere og daglejere var der ingen brug for, og navnlig de sidste slog sig da på knapmageriet. Der kunne tjenes ganske godt ved denne husindustri, og derfor hed det senere i Hostrup sogn: >Det er bedre at være knapmager end bonde !\& Men hans anseelse var kun ringe. Bondearistokratiet, som især havde udviklet sig i de gode tider ved århundredskiftet, ville ikke anerkende ham, selv om han sad $i$ gode kår, og det kunne ikke tænkes, at en bonde ville nedværdige sig til at blive knapmager.

Det var da også en husmand, Johan Christian Wermer, der har den største fortjeneste af knapmageriets udvikling og opsving. Han er født den 13. febr. 1762 i Lille Emmerske, Tønder landsogn, og lærte knapmageriet af morfaderen, Johan Filip

") At der fra gammel tid fandtes knapmagere i Hostrup sogn, fremgår af kirkebøgerne. Ifølge velvillig meddelelse af nuværende sognepræst, hr. J. Hansen, nævnes allerede 1747 ,Hans Jürgen, Knopfmacher von Jeysing «, 1764 *Hinrich Knöpfmacher aus Hostrup , 1766 ,Christen Nielsen, Knopfmacher in Jeysing^, 1767 Peter Petersen og Peter Wolssen i Rørkær og 1770 Søren Sørensen i Jejsing. 
Wermer, husmand i Hostrup; denne udpegedes af en senere slægt som den, der havde bragt knapmageriet til sognet. Hvor Filip Wermer kom fra, er uvist; i kirkebogen omtales han som »ein Deutscher von Geburt«. Han døde 1780.

Først og fremmest gjaldt det for Wermer at sikre sin stilling og virksomhed. Som for alle andre af datidens begyndende industrivirksomheder var midlet en kgl. koncession. For sit redkommende фnskede han ret til omløberhandel, d.v.s. til uden om markeder og købmænd at afsætte sine knapper. Kun med en sådan i lommen mente han sig betrygget.

Hans ans $\varnothing$ gning af 26 . april 1797 giver gode oplysninger om alle de vanskeligheder, han havde at kæmpe med. kongelig undersåt og fast beboer i Hostrup sogn og er derfor if $\varnothing$ lge lands lov og ret berettiget til i mit fædreland at ernære mig og min familie på en ærlig måde. Jeg har i min ungdom lært knapmageriet af min bedstefader, og dette er det erhverv, hvormed jeg kan fors $\emptyset$ rge kone og børn. Men afsætningen af knapperne er kun ringe ude på landet $i$ en lille landsby, hvor der kun bor nogle få bolsmænd og kådnere, og desuden findes der rundt omkring i amtet talrige knapmagere, der ligesom jeg skal have det daglige brød.« Derefter fortæller han, at han dog hidtil med n $\phi d$ og næppe har kunnet klare sig, men det værste har været, at han efte har været udsat for at miste »meinen ganzen Krahm《 og således blive ulykkelig for hele livet. Toldbetjentene har nemlig ikke altid villet lade ham spassere«, da han ikke har kunnet fremvise den kgl. koncession, der forlangtes af dem, der rejste omkring i landet med de af dem forfærdigede varer. For nu $\gg$ for fremtiden at blive befriet for denne forlegenhed og ligesom mine medborgere i ro og mag at kunne afsætte mine varer«, ans $\phi g e r$ han om en koncession. ${ }^{3}$ )

Ligesom for mange andre ans $\emptyset$ gere blev det også for Wermer en lang og trælsom vej at nå gennem embedskontorerne, og sk $\phi$ nt han blev støttet af amtmanden i T $\varnothing$ nder, afslog kommercekollegiet hans ans $\varnothing$ gning og henviste ham til at bes $\phi g e$ markederne og i $\varnothing$ vrigt ligesom de $\varnothing$ vrige knapfabrikanter at oplægge sine varer til salg hos de handlende; »omløberhandel kan ikke tillades «.4)

Wermer lod sig imidlertid ikke afskrække ved dette nederlag. 
Han fandt snart på en ny udvej, der var lige så vel egnet til at forbedre hans stilling og kår. Han ønskede at udvide sit marked til kongeriget, og for at kunne sælge sine knapper tilstrækkelig billigt ansøger han om at måtte indf $\varnothing \mathrm{re}$ dem toldfrit til Danmark eller mod en årlig rekognition på $4 \mathrm{rdr}$. Til st $\phi t t e$ for sin ans $\phi g$ ning gjorde han gældende, at toldloven af 1 . febr. $1797 \mathrm{i}$ den grad havde skadet afsætningen for ham, at han havde måttet afskedige alle andre medarbejdere undtagen sønnen.

Denne gang havde Wermer held med sig. Generaltoldkammeret anså knapperne for så gode, at det var rimeligt gennem en toldnedsættelse at lette deres afsætning. Kommercekollegiet nærede vel nogle betænkeligheder af hensyn til den i K $\phi$ benhavn etablerede fabrikant Rudolphi, men da denne imidlertid havde opnået den store begunstigelse at levere knapper til hæren og desuden havde fảet tilladelse til at indf $\varnothing$ re toldfrit 20 skippund uforarbejdet tin til anvendelse ved sin fabrik, blev begge kollegier enige om at anbefale, at Wermer for sine knapper fik tolden nedsat til det halve. Ved kgl. resolution af 26 . aug. 1803 stadfæstedes dette forslag. $\left.{ }^{5}\right)$

Wermer kunne nu med godt håb se fremtiden i møde. Kort efter åbnede der sig endog nye strålende udsigter for ham. Myndighederne var blevet opmærksomme på hans virksomhed. Den 9. maj 1809 befalede kongen generaltoldkammeret og kommercekollegiet at skaffe oplysninger om, hvor vidt der i landet fabrikeredes de nødvendige metalknapper til militær brug, og om det af mangel på tilstrækkelig indenlandsk fabrikation skulle være n $\emptyset \mathrm{d}$ vendigt at give tilladelse til dette slags knappers indf $\phi$ rsel..$\left.^{\circ}\right)$ Wermer var ikke sen til at gribe den mulighed, der måske var åbnet for ham. Han ans $\varnothing$ ger om toldfri indf $\phi$ rsel af sine knapper til Danmark for at kunne blive leverand $\phi \mathrm{r}$ til den kgl. militæretat. Den 23. november 1811 får kommercekollegiet befaling til at indhente oplysning om, til hvilke priser ansøgeren sælger sine metalknapper, og hvor vidt armeen kunne være tjent med hans vare.2)

Der blev straks givet befaling til amtmanden i T $\phi$ nder at indsende et fuldstændigt prøvekort af de knapper, som Wermer forfærdigede, med vedføjede priser på enhver sort. Så snart dette var modtaget af kollegiet, blev det tilstillet det kgl. generalkom- 
missariats kollegiet, som efter at have indhentet en erkæring fra det militære varedepot svarede, at de af Wermer forlangte priser i slesvig-holstensk kurant, når de beregnes til dansk kurant, ville med transportomkostninger og konsumtion $\mathrm{m}$. v. beløbe sig til 5 pr. dusin og således langt overstige den betaling af respektive 48 og 24 pr. dusin, for hvilken pris de til militæretaten brugelige store og små tinknapper leveres af knapmager Rudolphi i København. Det militære varedepot udtalte ganske vist, at Wermers knapper måske var af større styrke, men erfaringen havde vist, at Rudolphis fabrikat altid havde holdt ud over den bestemte tid. Generalkommissariats kollegiet fandt derfor ingen anledning til at entrere med Wermer om nogen leverance til hæren.

Forhåbningen om at blive leverand $\phi r$ til hæren var således slået fejl. Alligevel gik Wermer ikke tomhændet ud af denne forhandling. Kommercekollegiet gjorde opmærksom på, at »de forandrede konjunkturer og det ufordelagtige forhold af kursen så betydeligen har indskrænket de forhen fra de handlende i Jylland modtagne bestillinger, at han savner den nødvendige behøvende afsætning til sin virksomheds vedligeholdelse.« Kollegiet slutter derfor med at anbefale Wermer til fuld toldfrihed for hans knapper, og en kgl. resolution af 6 . april 1812 billiger dets indstilling.7)

Dermed var Wermer tilfredsstillet. Han kunne nu fortsætte sin forretning og drive den med fordel indtil sin d $\varnothing d$ den 8. febr. 1838.

Hans eksempel havde imidlertid smittet. En anden knapmager i Hostrup sogn, Jakob Matthiesen i Solderup, havde allerede tidligere optaget konkurrencen med Wermer. 1818 opnåede også han tilladelse til at indf $\phi r e$ sine knapper toldfrit til Danmark." Man skulle nu tro, at han ligesom Wermer ville have ladet sig nøje med at udnytte de rettigheder, han var bleven forlenet med. Dette blev dog ikke tilfældet. Hans iltre temperament og hans iderige, men noget uklare hoved lod ham stadig udtænke nye muligheder, nye veje, der måtte fors $\phi$ ges, og han indsender den ene ans $\phi$ gning efter den anden til kongen. - Det var Wermers gamle tanke om ret til at husere, der går igen. Den 18. juli 1819 ønsker han at sættes $i$ stand til at sælge sin knapper stoldfrit til købmændene i byer og flækker og til landbefolkningen og uden at betale nogen told at sælge knapperne på markederne $\ll^{1}$ ). Som praksis 
var, blev denne ans $\emptyset$ gning sendt til amtmanden i T $\phi$ nder amt, for at han kunne afgive sin erklæring. Denne er højst besynderlig og viser tydeligt, hvor lidt han den gang forstod hele spørgsmålet. Han synes at gå ud fra, at Matthiesen allerede tidligere havde en koncession, men glemmer, at det var toldfriheden, han havde opnået, - og anbefaler ham til denne. Denne betænkning. kunne selvfølgelig ikke gavne Matthiesen. 1821 kommer han imidlertid igen med sin ansøgning. Han udtaler i denne, at salget. af knapperne sker væsentlig til købmændene i byerne; men dette er ikke tilstrækkeligt, »thi når man falbyder sin vare til disse, giver de mindre for den, end den koster dem i England «. Derefter tilf $\varnothing$ jer han ret spydigt: »Den største skade, jeg vil anrette, er den, at de prøjsiske, polske og tyske jøder får mindre betaling for deres vare, og at det indenlandske fabrikat fortrænger det udenlandske. Det synes mig tilgiveligt, at jeg beder om den samme ret, som de udenlandske jøder har $\ll^{1}$ ).

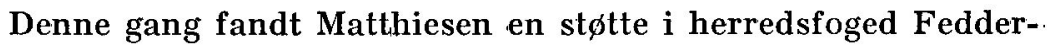
sen og amtmanden. Den første hævder bestemt, at knapmageriet. er en kunst og ikke et borgerligt erhverv, og der beh $\emptyset$ ves derfor ingen koncession. Knapmageriet kan slet ikke finde sted i byerne, fordi de store priser på varerne der, skatterne og den højere dagløn g $\phi$, at der ikke der kan konkurreres med tyskerne og englænderne. Medens ans $\emptyset$ gerens knapper kun kan erholdes hos købmændene, har de udenlandske jøder tilladelse til at falbyde deres. fabrikat på markederne. Han holder på, at den hjemlige knapmager må have samme ret som den fremmede. Heri er amtmanden enig med herredsfogeden. »Den indf $\varnothing d t e ~ b \phi r ~ i$ ingen henseende stå tilbage for jøderne, hvad rettighederne angår. Jeg kan derfor ikke undlade at anbefale $J$. Matthiesen til, at det tillades. ham at afsætte sine knapper på markederne. $\ll^{2}$ )

Trods denne værdifulde st $\phi$ tte blev resultatet et fornyet afslag. Matthiesen måtte ligesom Wermer lade sig nøje med toldfriheden.

II.

Imidlertid var knapmageriet vokset $\mathrm{i}$ betydning. Flere og flere gav sig af med det lønnende erhverv og $\emptyset$ nskede, som rimeligt. 
var, at blive delagtige i de samme fordele, der var tilstået Wermer og Matthiesen. I årene omkring 1820 indsendtes en mængde ans $\varnothing$ gninger. Undertiden misforstod man ganske, hvorom det drejede sig, og i det uendelige varierede man sine ønsker og klager. Da disse ans $\emptyset$ gninger på mange måder kaster lys over spørgsmålet og viser ans $\varnothing$ gernes nærmere forhold og stilling, skal de omtales lidt udf $\varnothing$ rligere. Den koncession, som det stadig drejer sig om, er tilladelsen til toldfri udf $\varnothing$ rsel til kongeriget og ikke, som Wermer og Matthiesen forgæves havde søgt at opnå, tilladelse til omløberhandel.

Først melder Christian Johannsen Wermer sig. Han indsender sin ansøgning den 7. novbr. 1818. Han er en $s \varnothing n$ af $\gg$ den gamle Wermer og har lært knapmageriet af denne. Han skriver: "Medens det tidligere har været tilladt at drive dette erhverv uden koncession, er det nu anderledes, idet der let kan lægges hindringer $i$ vejen fra de med koncession forsynede knapmagere, ligesom også det kgl. amt i Tønder har nægtet mig passerseddel til udf $\varnothing$ relsen af mine knapper.\&-Hertil svarer amtet i sin indstilling: » Hidtil har de mange knapmagere, der findes i Hostrup sogn, kunnet drive deres profession uden koncession og uden at betale nogen afgift til det kongelige amts register, men så begyndte nogle personer, som ikke engang havde lært knapmageriet ordentligt, at købe knapper hos de fattige knapmagere eller at tiltuske sig dem for gammelt tin, som de opk $\emptyset$ bte omkring på landet, og de huserede nu med disse knapper både $\mathrm{i}$ provinsen og $\mathrm{i}$ Danmark. Dette uvæsen blev drevet så vidt, at de med koncession forsynede knapmagere blev opmærksomme herpå og fik udvirket, at det kgl. amt nægtede at udstede rejsepas til nogen, når han ikke var $i$ besiddelse af en koncession eller attest, der beviste, at de knapper, han rejste omkring med, var forfærdiget af ham selv.\&

Amtet indstillede ans $\varnothing$ geren til at erholde en koncession til at forfærdige metalknapper. Denne ville blive udstedt af det SlesvigHolsten-Lauenborgske kancelli. »Hvad den toldfri indf $\varnothing$ rsel til Danmark angår, må henvendelse finde sted til det kgl. generaltoldkammer og kommercekollegiet, når koncessionen er givet. $4^{2}$ )

Den 28. novbr. 1818 møder S $\phi r e n$ Jensen i Jejsing med sin an- 


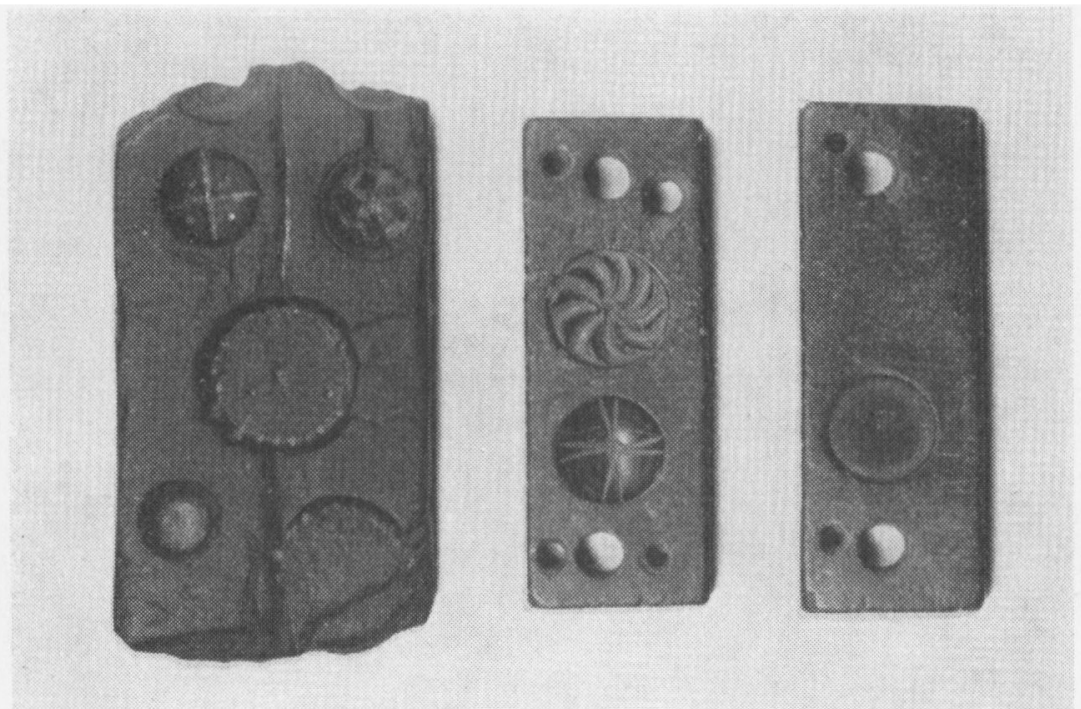

Stobeforme til knapper, Tønder Museums samling (fot. Fileming \& Vesteryuard).

sç̧ning. Han tilbyder at »erlagges en årlig rekognition på 6 rbdr., men vil til gengæld have lov til at drive et metalst $\not b e r i$, navnlig af metalknapper, og selvf $\phi$ lgelig toldfrihed. Som min faders ældste søn måtte jeg allerede som 8-årig dreng være ham behjælpelig i forretningen og har senere arbejdet på hans værksted. Da der nu intet borgerligt håndværk må drives på landet uden koncession, er jeg af $\emptyset$ vrigheden bleven opfordret til at ans $\emptyset$ ge om en sådan. Da jeg, som allerede bemærket, kun driver metalst $\varnothing$ beri ved forfardigelse af knapper og afsætter disse i store partier til $k \phi b$ mændene i de omliggende byer, Tønder, Aabenraa, Flensborg og Haderslev, og desuden $i$ de narmestliggende byer $i$ kongeriget Danmark, så kan jeg ikke skade det egentlige metalst $\varnothing$ beri som borgerligt erhverv, da det som regel slet ikke giver sig af med at lave knapper.»

Amtet er straks klar over, at Søren Jensen egentlig vil have tilladelse til at drive metalst $\varnothing$ beri, men da denne profession for meget griber ind $i$ de lavsmæssige metalst $\varnothing$ beres industri, idet han også vil kunne forfærdige lysestager, håndtage, o.s.v., kan 
en sådan koncession ikke tildeles ham. Han må ligesom de фvrige knapmagere lade sig n $\varnothing \mathbf{j e}$ med en almindelig koncession. ${ }^{2}$ )

Den 5. juni 1819 ans $\emptyset$ ger Boh Gottfriedsen i Jejsing om koncession og toldfrihed. »Jeg har $\mathrm{i}$ min ungdom laert at lave metalknapper for bondestanden, og endnu driver jeg dette håndværk, da jeg ikke er skikket til andet legemligt arbejde. Det ville være mig umuligt på anden vis at fortjene brødet til min kone og fire børn. Da jeg hidtil herhjemme har solgt mine knapper til andre, som handler med dem, har min fortjeneste kun været ringe, men værre er det dog, at jeg ofte har måttet sælge på kredit, hvorved jeg i nogle år har haft et tab af over 400 mark. Dette kan ikke blive ved, og jeg må, hvis jeg ikke skal gå helt til grunde, finde en anden måde, hvorpå jeg kan afsætte mine knapper; thi det er for den lille mand meget vanskeligt $i$ disse tider at fors $\phi$ rge fire til dels uopdragne børn. De små knapper, som tidligere brugtes så meget af bondestanden, er der ingen videre efterspørgsel on, og desuden kaster de ikke meget af sig. Jeg er derfor kommen i den nødvendighed selv at måtte rejse omkring med mine knapper i Jylland og de danske provinser, hvor de svære knapper bliver brugt meget, og hvorpå der er mere at fortjene. Men skal mine knapper fortoldes her, kan jeg ikke klare mig; thi jeg vil ingen afsætning få her; det er kun de billige, man kan sælge. Jeg trænger til at få tilladelse til uhindret at dyrke mit håndværk og at få toldfrihed, så jeg kan handle i Jylland og de danske provinser med de af mig selv forfærdigede knapper, hvis jeg̊ skal være i stand til på en ærlig måde at fors $\phi$ rge min familie.« Amtet anbefaler ham. ${ }^{2}$ )

Ventetiden blev meget lang for knapmagerne. Som sædvanlig gav myndighederne sig god tid med deres overvejelser. Boh Gottfriedsen tabte omsider tålmodigheden, og efter at han flere gange forgæves havde henvendt sig til kancelliet, afsender han den 3. juli $1824-5$ år efter indgivelsen af sin ans $\varnothing g n i n g-f ø l g e n d e$ skrivelse direkte til kongen:

\Jeg er en svagelig mand på 60 år og kan ikke mere foretage de besværlige rejser, men ser mig nødt til at sende mine knapper med posten fra den ene by til den anden. Når jeg skal betale denne transport og min årlige rekognition, der er 4 rbdr., og des- 


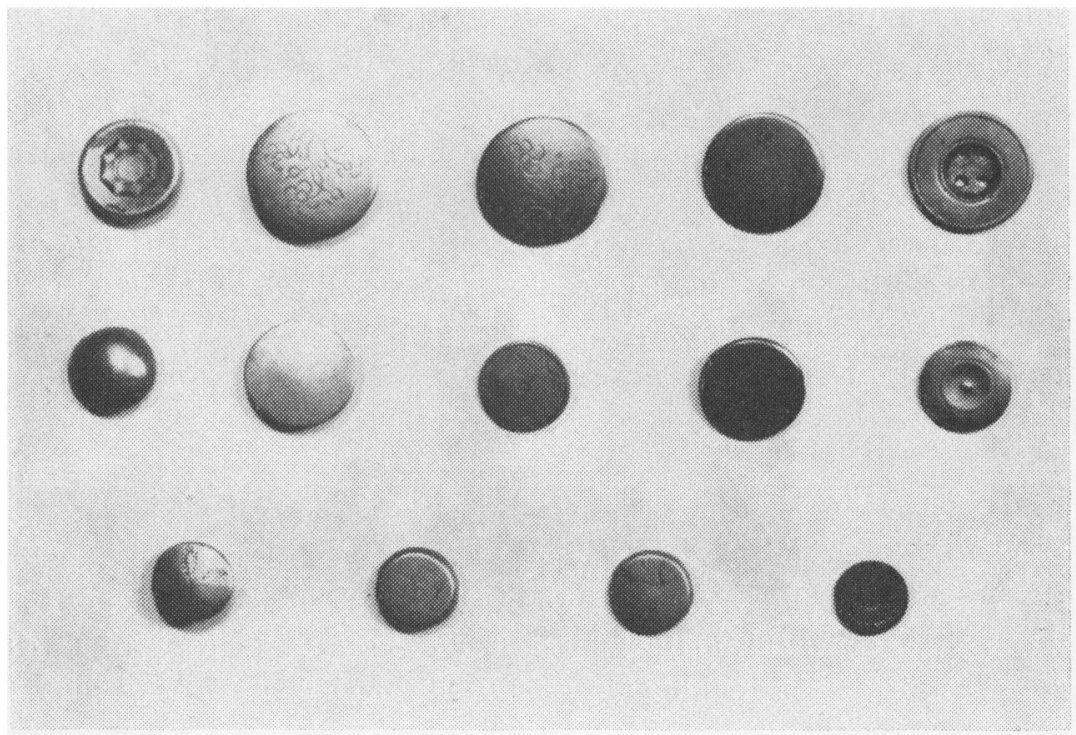

Knapper fra Tonder Museums samling (fot.: Fleming \& Vestergaard).

uden skal lade knapperne fortolde, er det umuligt for mig at skaffe det daglige brød til mig og mine. Da knapmageriet er det eneste arbejde, hvorved jeg kan ernære mig, og min nabo, Johan Chr. Wermer, allerede i mange år har kunnet sælge sine knapper toldfrit, håber jeg, at den samme allerhøjeste nåde også må vederfares mig.

Gid det dog måtte behage Deres kgl. majestæt snart at glæde mig med en allerhøjeste resolution.

Dette er mit eneste $\emptyset n s k e$ og allerunderdanigste bøn. $\left.\otimes^{2}\right)$

Knapmagerne har nok haft en lille anelse om, at en kgl. resolution var i opmarch; thi i tiden fra den 9. sept. 1823-den 24. febr. 1824 møder ikke mindre end 12 nye ans $\varnothing$ gere frem. De erklærer næsten alle, at de er meget fattige, og at de har lært knapmageriet i deres ungdom, da de »på grund af svaghed ikke har kunnet påtage sig strengt legemligt arbejde«.

Alle disse ansøgninger $g \varnothing$ r efterhånden indtryk på de lokale myndigheder.

Herredsfoged Feddersen fremhæver i varme ord, hvor glædeligt 
det er, at det hjemlige knapmageri kan bruge det gamle metal, og at denne kunst formindsker afsætningen af tyske og engelske knapper, - men det er ikke noget borgerligt erhverv. Derfor beh $\phi$ ves der ikke nogen koncession. "Hvis det er det kgl. amts mening, at der på landet kun må benyttes spaden og leen, så indser jeg ikke, hvorfor det ikke ser på samme måde på en mængde andre beskæftigelser, f. e. b $\phi$ rstenbinderiet. B $\phi$ rsterne laves $i$ aftenstunden og saelges ligesom knapperne til købmandene. Knapmagerne må ikke husere med deres varer, »men sælge dem til k $\phi$ bmændene i byerne; det samme g $\phi \mathbf{r}$ manden fra Elberfeld og Birmingham. Når en undersåt her i landet skal lose koncession og betale rekognition og andet gebyr, tilsidesættes han for udlændingen. Det er et fænomen, der står i fuldstændig modsætning til vor vise lovgivning. En koncession er efter vore love hverken mer eller mindre end en undtagelse fra regelen. Under disse omstændigheder mener jeg, at der b $\phi \mathbf{r}$ gives supplikanterne afslag, og at der meddeles kancelliet, at forfærdigelsen af metalknapper kan drives uhindret. Den borgerlige frihed og kongens suverænitet er ord af lige værdi, såvel $i$ teori som praksis. Man ville åbenbart handle mod sin embedsed, hvis man tog den ret fra borgerne, som er tilladt udlændingen. Jeg går ud fra disse grundsatninger, og jeg tror, at jeg ikke har taget fejl. $\star^{2}$ )

Amtmand Matthiesen går i sin indstilling let hen over herredsfogedens ret hvasse bemærkninger. Man har at rette sig efter, at enhver landhåndværker if $\varnothing$ lge sallerh $\emptyset$ jeste forordning « er forpligtet til at løse en koncession. Han overser således helt, at Feddersen netop hævder, at knapmageriet ikke er noget håndværk; han vil åbenbart ikke ind på dennes argumenter. For resten mener amtmanden, at for $\varnothing$ gelsen af disse håndværkere ingen skade vil være til, men tværtimod bringe denne industri fremgang. Han kan derfor anbefale ans $\varnothing$ gningerne, men henstiller til kancelliet, om supplikanterne på grund af deres fattigdom ikke kan fritages for gebyr eller $i$ det mindste slippe med at betale halvdelen af dette.?)

Kancelliet har imidlertid taget sigs sammen og den 28 . juni 1823 meddelt kommercekollegiet, at det har tilstået Christian J. Wer- 
mer, S $\varnothing$ ren Jensen, Boh Gottfriedsen og Rasmus Frederiksen koncession til at forfærdige metalknapper, men da samtlige supplikanter har bedt om toldfri udførsel til Danmark af deres knapper, qnsker det, at kollegiet vil tage denne sag op til behandling.

Den 27. decbr. s. å. sender kollegiet ansøgningerne med bilag og prøver af de knapper, som de fire knapmagere har lavet, til fabrikdirektøren, etatsråd Lehmann, for at han kan afgive betankning. Han behфver kun tre dage til dette arbejde.

Efter den indledning, som foran er omtalt, går han over til sagens realitet. Han $\gg$ kender ikke de grunde, hvorfor disse priselige industrifrembringelser ikke nyder aldeles toldfrihed; men er der i dette jjeblik vanskeligheder at befrygte ved at ophæve tolden, foreslår han, at de forfærdigede knapper kan indføres i kongeriget for $1 / 4$ af den for st $\varnothing$ bte og slebne knapper bestemte told. \$Da en slig fattigmands industri fortjener at opmuntres benstiller han, at shevillingerne udfærdiges for disse fattige folk uden betaling«. »I stedet for at være genstand for heskatning, skulle denne sag hellere nyde præmie. ${ }^{1}$ )

Derefter indgav kollegiet sin forestilling til kongen. Det gjorde navnlig gaeldende, at det ifølge de officielle beretninger er de fattige beboere $i$ den ufrugthare del af T $\phi$ nder amt, der driver knapmageriet, og at knapperne er $\gg$ både billigere og bedre end de tyske og engelske, som kræmmere og $\mathbf{j} \phi d e r$ f $\phi \mathrm{rer}$ ind $\mathrm{i}$ landet $\ll$. Kollegiet er derfor enigt med fabrikdirekt $\varnothing$ ren og kancelliet $i$, at der til opmuntring af denne industri bør gives toldfrihed, og det så meget mere, som der ellers ikke kan konkurreres med Wermer og Matthiesen.

Hidtil er tilladelsen til knapmageri bleven givet af kancelliet, og der er for den betalt en årlig rekognition på 4 rbdr. Da toldbegunstigelsen imidlertid ligger under generaltoldkammeret og kommercckollegiet, er man bleven enig med kancelliet om, at de fremtidige privilegier til knapmageri og den toldfri indf $\varnothing$ rsel til Danmark af knapperne skal udstedes ad mandatum af kollegiet, hvilket også vil ske for deres vedkommende, som allerede har erholdt en koncession. Af hensyn til knapmagernes trang vil 
privilegiet blive udstedt uden betaling. Den 31. marts 1824 faldt den $\mathrm{kgl}$. resolution $\mathrm{i}$ overensstemmelse med indstillingen..$^{10}$ )

Hele denne affære fik for $\varnothing v$ rigt et lille efterspil. Den 9. sept. 1824 indgav otte andre knapmagere ans $\varnothing$ gning om at erholde privilegier. De har »i dag « fået befaling af фvrigheden, at de må indstille deres arbejde, indtil de har fået bevilling. $\gg$ Hvad skal vi gøre $i$ vor store $n \varnothing d$ ! Vi er alle fattige og sidder med en stor familie, som hver dag skriger om brød; men hvor skal vi tage det fra? Vi er i den pinligste stilling! *

Amtmanden kommer dem til hjælp med sin anhefaling, og han udtaler $\mathrm{i}$ den $\emptyset$ nsket $\mathrm{om}$, at de snart må blive hjulpet, da det under daglig mulkt er dem forbudt at arbejde på deres knapper. En måned derefter fik de deres privilegier."1)

Amtmand Peder Matthiesen har atter, som så mangen en gang fǿr og senere talt knapmagernes sag. Han var dem altid en god talsmand og en pålidelig støtte. Altid havde han et åbent $\emptyset$ re for deres sorger og bekymringer, og altid havde han den fulde forståelse af, at her var der tale om en sag, der fuldt ud fortjente at ophjælpes og st $\phi t t e s:$ den gav mange fattige mennesker mad og gjorde deres tilværelse nogenlunde sorgfri, og det på en tid, der var meget vanskelig for »den lille mand«. Knapmagerne i Hostrup sogn folte dette og var ham taknemmelige for alt, hvad han gjorde for dem; de vidste, at han var deres ven.

\section{III.}

Man skulle nu have troet, at de hostruper knapmagere var tilfredsstillet. Vel havde ingen af dem opnået den ret til huseren, der, når alt kom til alt, var deres фnske og mål. Koncessionen sikrede dem dog mod indgreb i deres erhverv, og toldfriheden gjorde det muligt for dem at afsætte deres produkter over hele landet. Alligevel kunne de ikke slå sig til ro. De havde hidtil måttet finde sig i meget, døjet mange skuffelser, og deres sind var lidt efter lidt blevet bittert og mistænksomt; de følte sig aldrig ret tilfreds, og de havde stadig nye planer og nye $\varnothing$ nsker.

Det gjaldt nu for dem at blive fritaget for den årlige rekognition. Otte knapmagere i Hostrup og Rørkær andrager den 8. okt. 1825 om at slippe for den og anbefales af amtmanden, medens 
otte andre, hjemmehørende $\mathrm{i}$ Jejsing, vil nøjes med at blive fritaget for rekognitionen for 1825. Amtmanden finder, at det ikke kan nægtes, at betalingen af den ikke helt ubetydelige rekognition kan falde disse noget vanskeligt, og da de først fik deres privilegier hen i sept., henstiller han, at halvdelen af den årlige afgift bliver dem eftergivet. For $\emptyset v$ rigt g $\emptyset \mathbf{r}$ han opmærksom på, at amtstuen har truet dem, der ikke har betalt den forfaldne rekognition, med »eksekutive tvangsmidler $\ll$, og at han derfor må bede om en hurtig afgørelse. ${ }^{11}$ )

På samme tid finder der forhandlinger sted mellem kollegiet og finansdeputationen angående rekognitionen. Kollegiet finder, da knapmagerne er fattige og deres fortjeneste kun ubetydelig, at de fortjener al mulig underst $\varnothing$ ttelse; det er derfor tilb $\varnothing$ jelig til at andrage på allerhøjeste sted om ophavelse af rekognitionen, da denne kun har ringe betydning for den kgl. kasse. Da finansdeputationen intet har derimod, ophæves rekognitionen ved kgl. resolution af 5 . april $1826 .{ }^{12}$ )

Nu møder de otte knapmagere fra Jejsing atter op. Deres andragende ledsages denne gang af en fattigattest, udstedt af den vikarierende degn i Hostrup, N. H. Hansen, og sognefoged Hans Petersen. Man $\varnothing$ nsker ikke blot at blive fritaget for rekognitionen for 1825, men også, at den sag, der er anlagt mod dem af den kgl. amtstue, må blive hævet. Amtmanden henstiller »til højere sk $\phi n \ll$, om der ikke kan tages hensyn til medf $\varnothing l g e n d e$ fattigattest. - De opnåede intet, men kom igen næste år. Nu vil de have rekognitionen for 1824 tilbagebetalt sammen med oppebørsel- og skrivegebyr og sagen mod dem hævet. Skønt kollegiet »henlægger « deres andragende, tager de fat påny. Denne gang gælder det eftergivelse af den rekognition, de skylder for året 1825. Det utrolige sker. Kollegiet sender deres ansøgning til rentekammeret med en anbefaling, der støtter sig til »amtets vidnesbyrd om fabrikanternes uformuenhed«. Derefter h $\phi r e r$ man intet om denne sag. ${ }^{13}$ )

Man får det bestemte indtryk, at disse jejsinger knapmagere har været af en ret stridig natur, hårde halse og gennemsyrede af et mindre tiltalende rethaveri; thi man kan nok være enig om, at deres velfærd ikke kunne være afhængig af 3 rbdr. Når 
man gennemlæser de lange og ofte meget spidsfindige indlag, er man hurtig klar over, at de er skrevet af en dreven lommeprokurator. Hele denne affære hører ikke til de oplivende momenter i knapmageriets historie. Derimod må man beundre myndighedernes tålmodighed og korrekte optræden.

Atter havde knapmagerne fảet et af deres ønsker opfyldt. Skønt de åbenbart sad $i$ et blomstrende erhverv, havde de dog på grund af deres $\gg$ fattigdom og de ynkelige klager, for hvilke enevældens kollegier aldrig var utilgængelige, opnået at blive fri for den mådeholdne ydelse, regeringen hidtil havde pålagt dem. Alligevel kunne de dog ikke helt holde sig i ro. Skønt det kun lidet stemmede med deres fattige stilling, som de stadig havde udmalet, $\phi$ nskede de at udvide deres bedrift og få ret til at benytte medhjælp $i$ deres forretning. De fattige knapmagere $i$ Hostrup sogn var ved at blive industridrivende i storre stil.

Allerede i 1823 havde Jakob Matthiesen i Solderup indsendt ct andragende til kongen om at holde medhjælpere $i$ sin forretning. $\left.{ }^{2}\right)$ Herredsfoged Feddersen blev anmodet om en indstilling; men han misforstod aldeles Matthiesens hensigt, idet han kun taler om hjælp af børn og gamle koner, der altid har været benyttet til pudsning og polering af knapperne, medens Matthiesen selvf $\phi$ lgelig tænkte på svende og lærlinge. Spфrgsmålet blev den gang stillet $\mathrm{i}$ bero, men kom atter frem i året 1826 .

Det er amtmand Matthiesen, som nu tager sagen op. Det skete på foranledning af en $\mathbf{i}$ Jejsing boende knapmager, hvis navn ikke nævnes. Amtmanden udtaler, at det forekommer ham, at det $b \phi r$ stå de med koncession forsynede knapmagere frit at antage loxrlinge. Da han imidlertid ikke ved, om der er nogen bestemmelse $i$ så henscende, har han udsat afgørelsen af dette spørgsmål og henvender sig nu til kommercekollegiet for at få oplyst, om de nævnte knapmagere uden særlig tilladelse kan holde larlinge. Han udbeder sig $i$ den anledning en resolution og påviser de grunde, der synes ham at tale for, at der gives et bekræftende svar på sp $\phi$ rgsmålet. »Det vil være kollegiet bekendt, « skriver han, »at de i Tønder omegn forarbejdede knapper udmærker sig ved deres bonitet og deres billige pris. Desuden beskæeftiger denne industri et ikke lille antal mennesker, hvilket har 
sin store betydning pá en tid, da landbruget ikke indbringer ret meget. Derfor er det heldigt, både for omegnen og for køberne af denne handelsvare, at knapmageriet udvikler sig. Knapmagerne må ofte foretage rejser for at afsatte deres knapper. Derfor oplarer de deres børn, og hvis de ingen har, fattige drenge i deres håndværk, en ret heldig foranstaltning, da disse unge mennesker derved bliver $i$ stand til at fortjene deres daglige brød, og desuden får de udsigt til $i$ fremtiden at ernare sig ved denne industri. Det vil derfor være meget gavnligt for knapmageriet, at der gives tilladelse til at holde lærlinge, ja, det kan endog siges, at det vil vare en nødvendighed, hvis ikke dette håndværk lidt efter lidt skal udd $\phi . \ll$ Amtmand Matthiesen slutter med at foreslå, at der gives knapmagerne i $\mathrm{T} \phi$ nder amt tilladelse til uden speciel hevilling at holde larlinge. Derimod finder han det mest hensigtsmassigt, når nogen ville holde svend, at dette kun vil blive ham tilladt, når denne er forsynet med en koncession. Da flere knapmagere venter på afgørelsen, vil amtmanden vare meget taknemmelig, on kollegiet snart vil tilstille ham en resolution $\left.{ }^{2}\right)$.

Kollegiet sender amtmandens skrivelse til kancelliet med anbefaling. Derefter går den til statholderskabets departement, hvis erklæring tildels går imod, at knapmagerne uden videre får tilladelse til at holde medhjælp. »Det kan ikke billiges, at der gives begunstigelser for det borgerlige erhverv på landet, og der er ingen særlig grund til, at der gøres en undtagelse her fra den almindelige regel.« Derimod forekommer det departementet »meget mere $\phi$ nskeligt $\ll$, at det omtalte erhverv fors $\phi$ gsvis pr $\phi v e s$ i byerne. Det $b \phi r$ tilkendegives amtmanden, at der ikke findes at være tilstrækkelig grund til at gøre en undtagelse fra de galdende forordninger, der angår de borgerlige næringsveje på landet, og at det derfor ikke kan tillades de koncessionerede knapmagere at benytte medhjælp uden udtrykkelig tilladelse ${ }^{2}$ ).

Denne erklæring sendes tilligemed en udtalelse fra magistraten i Tønder tilbage til kancellict. Dette udtaler nu, at det tror at være i overensstemmelse med kollegiet og magistraten, når det holder på, at de allerede $i$ landdistrikterne med koncession forsynede metalknapmagere får tilladelse til at holde medhjælp, og 
at det for fremtiden bemærkes $i$ koncessionen, at der må holdes larlinge og medhjælpere i deres erhverv. En kgl. resolution af 2. maj 1827 stadfæstede kancelliets forslag. ${ }^{14}$ )

Atter har amtmand Matthiesen vist sig som knapmagernes sande og formående ven, der altid havde deres vel for $\varnothing j e$. De har nu fået betydeligt bedre kår at arbejde under. Afsætningen stiger, og deres hele stilling er bleven mere betrygget; deres virksomhed udsxttes heller ikke for at »udd $\phi \ll$, når de ingen hørn har.

I alt blev der fra 19 . juni $1824-9$. juli 1835 givet koncession og toldfrihed til 40 knapmagere, af hvilke 37 boede i Hostrup sogn, 2 i Bylderup sogn og 1 i Sønder Løgum i Kærherred. Af Hostrup sogns 1077 beboere i året 1835 fik 216 eller ca. 20 pet. deres underhold ved knapmageriet.

Men også knapmagernes anseelse i sognet stiger fra nu af betydeligt. Man ser således, at en forhenværende knapmager, gårdejer i Jejsing, Peter Nielsen Petersen, indtager en ledende stilling som sognefoged i Hostrup. Senere bliver han også kommunefoged for den store Solvig kommune og er medstifter af sognets sparekasse. For sine fortjenester under krigen 1848-51 bliver han bel $\phi$ nnet med dannebrogskorset.

Knapmageriets blomstringstid varede ved til henimod midten af trediverne, - så begynder tilbagegangen.

Under de voksende vanskeligheder for knapmagerne genoptog de det aldrig helt opgivne ønske om at få tilladelse til at husere.

Den 30. juni 1834 ans $\varnothing$ ger Peter Hansen Petersen i Jejsing om en koncession. Han $\emptyset$ nsker »at husere med sine knapper i Jylland, såvel i dusinvis som i partier og at bes $\emptyset$ ge markederne 4 . Han fik sit privilegium, $\gg$ men det kan ikke tillades ham at husere med sit fabrikat i Jylland. ${ }^{15}$ )

Den 24. okt. 1837 udkom der en ny forordning, der forbød $i$ hertugdømmerne al huseren eller falbydelse af varer fra hus til hus uden for årsmarkederne. Fra dette forbud var undtaget handel med en mængde varer, der alle henhørte til $\gg$ hemmearbejder 4 .

Efter at knapmagerne havde sundet sig i nogen tid på de over- 
raskelser, som denne forordning sikkert har beredt dem, indsendte de en mængde ansøgninger for at få tilladelse til at husere. Da disse i løbet af ca $2 \frac{1}{2}$ år havde vandret omkring til alle myndigheder, blev det meddelt, at der var givet afslag. Knapmageriet kunne ikke komme ind under nogen af de i forordningen næunte undtagelsesbestemmelser. Det var et borgerligt erhverv. ${ }^{10}$ )

Selv om man havde været tilhøjelig til at forandre sin anskuelse på dette område, ville den omstændighed selvfølgelig have gjort sig gaeldende, at knapmageriet allerede på den tid var $i$ en rivende tilbagegang, og at det efter al sandsynlighed næppe ville kunne rejse sig igen. Hornknapperne havde holdt deres indtog på landet, og enhver kunne let indse, at de måtte sejre $i$ kampen: de var både billigere og mere praktiske end metalknapperne. Den unge generation foretrak disse nye knapper, og det var kun de ældre bønder med den røde eller grå \$lue« pá hovedet, knæhukser og den afstumpede trøje, der endnu holdt fast ved dem. »Bondeknapperne" passede ikke længer for den danske bonde. Han bortkaster alt, hvad der har været den $\gg$ usselige bondes « kendetegn. Bondeuniformen har levet sin længste tid. Lidt efter lidt gik »den gamle bonde $i$ graven og med ham bondeknapperne.

Omkring 1864 var knapmagerict i Tønder amt lagt på hylden.

\section{Henvisninger.}

1) Kommercekollegiet, industrifaget, journalsag, 1831, nr. 867.

2) Smstds., 1827, nr. 583.

3) Smstds., 1797, nr. 454.

4) Komm.koll., industrif., kopibog, 1798, nr. 261. - Skrivelse til amtmand Bertouch i Tønder amt, 17. 4. s. å.

5) Generaltoldkammerets danske forestillingsprotokol, 1803, nr. 41. Forestilling 11. 8., resolution 26. 8.

B) Gen.toldk. danske forestillingsprot., 1809, nr. 52, reskript 9. 5.

7) Komm.koll., industrif. forestillingsprot., 1812, nr. 19. Forest. 27. 2., res. 6. 4 .

8) Gen.toldk. tyske forestillingsprot., 1818, $\mathrm{nr}$. 21, forest. 14. 4. Hes. 22.4.

9) Komm.koll., industrif., journals., 1824, nr. 820 .

10) Gen.toldk. tyske forestillingsprot., 1824, $\mathrm{nr}$. 34, forest. 23. 3., Res. 31. 3. 
11) Komm.koll., industrif., journals., 1828, nr. 131.

12) Gen.toldk. tyske forestillingsprot., 1826, $\mathrm{nr}$. 48 , forest. 28 . 3., res. 5. 4.

13) Komm.koll., industrif., journal, 1828, nr. 871.

14) Gen.toldk. tyske forestillingsprot., 1827, $\mathrm{nr}$. 63, forest. 24. 4., res. 2 . 5 .

15) Komm.koll., industrif., journals., 1835, nr. 289.

16) Komm.koll., industrif. journal, 1840, nr. 1780, og 1842, nr. 109. 